\title{
Büyükşehir Belediye Sınırları İçinde Yer Alan Kırsal Yerleşmelerin Sorunları Üzerine Bir Değerlendirme
}

\author{
M. Alim ÇOPUROĞLU* \\ Süleyman Demirel Üniversitesi, Mimarlık Fakültesi, Şehir ve Bölge Planlama Bölümü, 32260, Isparta, \\ Türkiye. \\ *e-mail:acopuroglu@hotmail.com \\ Öz \\ Bu makalede Büyükşehir Belediye sınırları içinde kalan kırsal yerleşmelerin yaşamakta oldukları sorunlar ele \\ alınmakta ve bir değerlendirme amaçlanmaktadır. 2014 yılında yasalaşan 6360 sayılı "13 ilde Büyükşehir \\ Belediyesi Kurulması ile ilgili Kanun" uyarınca Türkiye'de Büyükşehir Belediye sayısı artırılırken bu nitelikteki \\ belediyelerin görev ve yetki alanları genişletilmiş ve ilgili il sınırları ile çakıştııılmıştır. Bu süreçte il sınırları içinde \\ yer alan kırsal nitelikli yerleşmeler (köyler) de yasal olarak bağlı oldukları ilçelerin uzantısında büyükşehrin \\ mahallesi haline gelmişlerdir. Sonuç olarak, özünde kentsel çevreler için kurgulanmış olan belediye ve imar \\ mevzuatı ile bu çerçevede oluşmuş çalışma ve hizmet anlayışı, benimsenen yaklaşımlar, projeler, programlar ve \\ uygulamalar alısıılmış şekilleriyle kırsal nitelikli çevreye taşındığın çeşitli sorunların ortaya çıktığı görülmektedir. \\ Bu amaçla 2015 yılında GAP Bölge Kalkınma idaresi için yapılan bir çalışmanın bulguları değerlendirilmektedir. \\ Çalışmada, Türkiye'de kentleşme, kentlerde yaşanan nüfus artışı ve Büyükşehir kavramının tarihsel gelişsimi \\ özetlenmekte ve Büyükşehirler ile ilgili mevzuat ve ülkedeki büyükşehirlerin nüfusları incelenmektedir. Bugün \\ gelinen noktada 6360 sayılı yasanın uygulanması ile ülkede yaşayan nüfusun kentsel ve kırsal yerleşmelere \\ dağılımının belirsiz duruma geldiği ortaya konulmaktadır.
}

Anahtar Kelimeler: Büyükşehir Belediyesi, kırsal yerleşim, 6360 sayılı kanun, nüfusun kentsel/kırsal dağılımı

\section{An Evaluation on the Problems of the Rural Settlements in the Metropolitan Municipal Boundaries}

\begin{abstract}
This article takes the current problems experienced in the rural settlements located within the metropolitan boundaries and aims to present an assessment. Act no. 6360 titled "Establishment of Metropolitan Municipalities in 13 Provinces" which was issued in 2014, has both increased the number of such municipalities and also enlarged their responsibilities and service areas up to provincial boundaries. Therefore, all of the settlements within the provincial boundaries including the ones with rural characters, have legally become neighbourhoods of the respective metropolitan municipality, parallel to the districts they belong. As a result, existing municipal and planning legislations which were basically developed for the urban environments and the related municipal practices, services, approaches, projects, programmes and implementations are all observed to cause problems when they are transferred into the rural environment in their original formats. Outputs of a study prepared for the Southeastern Anatolia Project (GAP) in the year 2015 are assessed. The article reviews the definitions and historical development of the urbanisation, urban population increases and the concept of metropolitan centres. Corresponding legislation and current size of inhabitants of the large cities are also presented. Existing ambiguity caused by the Act no. 6360 in the population distribution between the urban and rural areas is also exposed.
\end{abstract}

Keywords: Metropolitan Municipality, Rural Settlement, Law No. 6360, Urban/Rural Distribution of the Population 


\section{Giriş}

Bugün hızla kentleşen bir dünyada yaşıyoruz. Kentleşme hızı ülkemizde de çok yükseklerde seyrediyor. 1970'li yıllarda toplam nüfusun \% 38'i kentsel alanlarda yaşamakta iken bugün bu oran \% $80^{\prime}$ ler düzeyinde bulunuyor. Diğer taraftan kentlerde yaşayan nüfusun da her yıl gittikçe artan bir bölümünün büyükşehirlerde yerleştiği bir gerçek olarak kabul ediliyor. Küçük nüfuslu kentlerin barındırdığı nüfusun toplam kentli nüfus içindeki payı sürekli azalırken büyükşehirlerin payı her geçen gün büyümektedir. Bu süreçte büyük nüfusların yığıldığı mega kentlerin sayısı ve toplumsal yaşamdaki ağırlığı da artıyor. Bu trend dünyada olduğu gibi Türkiye'de de geçerli ve güncelliğini koruyor. Türkiye İstatistik Kurumu (TÜiK) 2015 yılı verilerine göre, bugün İstanbul 14.6 milyon nüfusu ile gerçek bir mega kent olduğunu ve kendisini izleyen (4.7 milyon nüfuslu) Ankara ile arasındaki farkın her geçen gün açılmakta olduğunu kanıtlıyor.

Günümüzde dünyada ve Türkiye'de kentleşme konusundaki en önemli sorunlar nüfusun mega kentlerde aşırı yığılmasından kaynaklanmaktadır. Ancak, bu makalede kentleşmenin daha tali ancak yine önemli diğer bir sorunu olan ülkemizde Büyükşehir Belediye sınırları içinde yer alan kırsal yerleşmeler ele alınmaktadır.

\subsection{Kırsal Alan ve Yerleșmeler}

Kentsel ve kırsal alan kavramları bir diğerine karşıt gibi görünseler de ancak diğerine referansla tanımlanabilen ve bir birini bütünleyen kavramlardır. Bu ikili yapıda; kalabalık nüfusu, sosyal ve ekonomik canlılığı, istihdam olanakları, fiziki altyapı ve sosyal donatılarının gelişmişliği ile kolay ulaşılabilirliği gibi nedenlerle kentler daha öncelikli konumda görünmektedirler. Köyler ve kırsal alan ise -özellikle dengesiz gelişmenin egemen olduğu yerlerde- sürekli göç veren ve nüfus kaybeden yerleşimler olmaktadır. Türkiye'de 1950'li yıllardan itibaren ağırlığını duyuran tarımda makineleşmenin tetiklediği kırsaldan kopma ve kentlere göç olgusu mevcut kırsal / kentsel yerleşim dağılımının temel nedenidir. Son yıllarda ulaşım ve iletişimdeki gelişmeler ile kamu hizmetlerinin yaygınlaşması nedeniyle eskinin ücra ve mahrumiyet yeri kırsal alan kavramı günümüzde değişmiş ve kentler ile arasındaki yaşam koşulları farkı kısmen kapanmaya başlamıştır. Bu süreçte, kırsal yerleşmelerden nüfus tutma kapasitesine sahip bir bölümünün yarı - kentsel özellikler kazandığı görülebilmektedir.

Ülkemiz mekanında mevcut bu nüfus ve yerleşim dağılımı, kırsal alanda yaşanan nüfus azalması ve kırsal yerleşimlerin nüfus tavanına yönelik son yıllarda hazırlanan üç resmi belgenin değerlendirmeleri şöyledir:

\subsubsection{KENTGES - Bütünleşik Kentsel Gelişme Strateji ve Eylem Planı 2010 - 2023}

04.11.2010 tarih ve 27749 sayılı Resmi Gazete'de yayınlanan ve günümüzde Çevre ve Şehircilik Bakanlığı tarafından izlenen "Kentges - Bütünleşik Kentsel Gelişme Strateji ve Eylem Planı 2010 2023"nda kırsal alan aşağıdaki şekilde yer almaktadır:

"Kentleşme süreci, kentlerin kırsal alanlara yayılması biçiminde geliştiği için, kırsal yerleşmelerin fiziksel, sosyal ve ekonomik yapıları üzerinde dönüştürücü etkisi olmaktadır. Diğer yandan, yatırım projeleri, kırsal alanları doğrudan etkilemektedir. Kırsal alanların kent üzerindeki en belirgin etkisi ise bu yerleşimlerden kentlere göç şeklindedir. Aslında göçün hem kırsal hem de kentsel alanlar üzerinde olumsuz etkisi olmaktadır. Nüfusun terk ettiği ve ülke ekonomisine katkısının azaldığı kırsal alanlar, buna karşın taşıyabileceğinden fazla nüfusu barındırmaya çalışan kentsel alanlar, göç olgusunun etkisinin çift taraflı olduğunu göstermektedir. Kırsal kalkınmaya yönelik sistemli stratejilerin geliştirilmesi ve uygulanabilmesi önem taşımaktadır (Kentges, 2010).

\subsubsection{Kırsal Kalkınma Planı 2010 - 2014}

T.C. Tarım ve Köy Hizmetleri Bakanlığı tarafından uygulamaya sokulan "Kırsal Kalkınma Planı 2010 2014"te gerekçe; "Türkiye geniş kırsal coğrafyaya ve nüfusa sahip bir ülke olarak, ulusal kalkınmaya ivme kazandıracak nitelikte önemli bir ekonomik ve beşeri kaynak potansiyeline sahiptir. Kırsal kesimdeki söz konusu potansiyelin harekete geçirilmesi; kırsal kesimin kısıtlarını ve ihtiyaçlarını, 
hizmetlerin ve yatırımların gerçekleştirilmesinde eşgüdümü, kaynak kullanımında etkinliği ve yerleşimlerin nüfus yoğunluğunu birlikte gözeten çok sektörlü ve bütüncül bir planlamayı zorunlu kılmaktadır" olarak açıklanmaktadır. Kırsal Kalkınma Planı'nın amacı ise "Bu çerçevede, Kırsal Kalkınma Planı'nın temel amacı; kırsal toplumun iş ve yaşam koşullarının kentsel alanlarla uyumlu olarak yöresinde geliştirilmesi ve sürdürülebilir kılınmasını sağlamaktır" olarak belirlenmektedir (T.C. Tarım ve Köyişleri Bakanlığı, 2011).

Kırsal Kalkınma Planı 2010 - 2014'ün hedef uygulama alanı TÜiK'in kırsal yerleşme tanımına uygun olarak 20.000 ve altı nüfusa sahip yerleşimler olarak belirlenmiştir. 2014 yılında plan ufkunun sona ermesi ile 6360 sayılı yasanın yürürlüğe girmesi aynı yıla rastladığından büyükşehir belediye sınırları içindeki mahalle statüsü kazanan kırsal nitelikli yerleşimlerde benzer politikaların nasıl izleneceği konusunda belirsizlik oluşmuştur. Bu durum, T.C. Gıda Tarım ve Hayvancılık Bakanlığı tarafından hazırlanan "Ulusal Kırsal Kalkınma Stratejisi (UKKS) 2014 - 2020" belgesinde “... mahalli idareler yapısındaki değişimlerden asgari düzeyde etkilenecek yeni bir kırsal alan tanımına ihtiyaç olduğu" şeklinde belirtilmiştir. UKKS'de ayrıca "bununla ilgili süreç Kalkınma Bakanlığı ve TüiK koordinasyonunda ilgili kurumlarla işbirliği çerçevesinde tamamlanması" gereği belirtilmiş bulunmaktadır (T.C. Gıda Tarım ve Hayvancılık Bakanlığı, 2014).

\subsubsection{BGUS - Bölgesel Gelişme Ulusal Stratejisi 2014 - 2023}

Kırsal alan tanımının yenilenmesi çalışmasının T.C. Kalkınma Bakanlığı ve TÜik tarafından gerçekleştirildiği yönünde bugüne değin herhangi bir gelişme görülmemektedir. Anılan Bakanlık tarafından hazırlanan ve 24.03.2015 tarih ve 29305 (mükerrer) sayılı Resmi Gazete'de yayınlanan "Bölgesel Gelişme Ulusal Stratejisi 2014 - 2023" belgesinde kırsal alan için aşağıdaki değerlendirmeler bulunmaktadır;

"Planlı dönemin başından beri, ülkemizdeki kırsal alan yerleşim deseni, kırsal kalkınmanın önündeki en önemli engellerden biri olarak kabul edilmiştir. Kırsal yerleşim deseninin; küçük, dağınık ve parçalı yerleşim birimlerinden oluşması kırsal kalkınma politikalarının etkin bir şekilde hayata geçirilmesini sınırlamıştır. Gerek tarımdaki yapısal dönüşüm gerekse kırdan kente göç nedeniyle ekonomik ve demografik açıdan kalkınma için gerekli rasyonel ölçekten uzaklaşan kırsal yerleşimlerin artışı nedeniyle topyekûn kırsal kalkınma yavaşlamakta ve faaliyetlerin etkinliği azalmaktadır. Türkiye'de kırsal yerleşimler idari ayrıma göre, il ve ilçe merkezleri dışında kalan tüm beldeler ve köyler olarak tanımlanırken, diğer bir tanıma göre ise nüfusu 20 binden düşük tüm yerleşim yerlerini kapsamaktadır. Ikinci tanım temel alındığında bazı ilçe merkezleri de kırsal alan kapsamına girmektedir" (T.C. Kalkınma Bakanlığı, 2014).

\subsection{Büyükşehir Belediyelerinin Yasal Çerçevesi}

Ülkemizde daha önce de nüfusu milyonu aşmış kentler var olmakla birlikte büyükşsehir belediye yönetimi konusunda yasal tanım mevcut değildi. Bunun yerine, kendiliğinden gelişme sonucu il merkezindeki büyük kentlerin idari olarak belediye sınırları dışında, ancak bu kentlerle fiziki mekanda bütünleşmiş ayrı belediye teşkilatına sahip yerleşimler yer almaktaydı. Örneğin i̇stanbul Belediyesi'nden bağımsız ancak İstanbul'un sosyal, ekonomik ve altyapı olanaklarından yararlanan Esenler, Güngören, Ümraniye, vb. yerleşimler büyük nüfusları barındırıyordu. Aynı sorun İzmir'de Buca, Bornova, Gültepe, vb. örnekler için de geçerli iken göreli olarak daha kompakt bir yapıya sahip olan Ankara'da benzer bir durum yaşanmamıştır.

Büyükşehir Belediyelerinin mevcut statüleri zaman içinde yapılan mevzuat değişiklikleri ve eklememeler sonucu oluşmuştur. Bu konudaki başlıca yasal kaynaklar aşağıdadır:

\subsubsection{2 sayılı kanun}

Büyükşehir Belediyesi kavramı ilk kez 18.01.1984 tarihinde kabul edilen 2972 sayılı "Mahalli idareler ile Mahalle Muhtarlıkları ve ihtiyar Heyetleri Seçimi Hakkında Kanun" ile gündeme gelmiştir. Ülkemizde büyükşehir Belediyesi ifadesinin ilk kez kullanıldığı bu yasada ufuktaki yerel seçimlere hazırlık olmak üzere daha çok, büyükşehir belediye meclisinin seçim usulleri ile bağlı alt belediyelerle ilişkileri ve çalışma esasları yer almıştır. 


\subsubsection{0 sayllı kanun}

27.06.1984 tarihinde kabul edilen 3030 sayılı "Büyükşehir Belediyelerinin Yönetimi Hakkında Kanun" ile İstanbul, Ankara ve İzmir il merkezi belediyeleri "Büyükşehir Belediyesi" olarak kabul edilmiş ve yasadan önce ilgili iller ile aynı adı taşıyan belediyeler merkez ilçe belediyelerine bölünürken (örn. İstanbul'da Beyoğlu, Fatih, Kadıköy, Bakırköy, Üsküdar, vb.), daha önce merkezdeki yerleşme alanı ile fiziki mekanda bütünleşik olmakla birlikte bağımsız olan belediyeler (Örneğin Ümraniye, Esenler, vb.) de büyükşehir belediyesi altında ilçe belediyeleri şeklinde yeniden düzenlenmiştir.

Daha sonra, 1986 yılında 3306 sayılı Kanun ile Adana, 1987 yılında 3391 sayılı Kanun ile Bursa, 3398 ve 3399 sayılı kanunlar ile Gaziantep ve Konya il merkezlerindeki belediyeler de büyükşehir kapsamına alınmıştır.

İlerleyen dönemde kabul edilen kanunlar ile ülkedeki büyükşehir sayısı artarken, 3030 sayılı Kanun büyük ölçüde uygulamadan kalkmış, bazı hükümleri yeni yasalar içinde yeniden tanımlanmıştır.

\subsubsection{9 sayılı Kanun}

11.12.2003 tarihinde kabul edilen 5019 sayılı "Büyükşehir Belediyelerinin Yönetimi Hakkında Kanun Hükmünde Kararnamenin Değiştirilerek Kabulü Hakkında Kanunda Değişiklik Yapılmasına iliş̧kin Kanun" Büyükşehir sınırlarını; nüfusu 5 milyondan büyük kentlerde (İstanbul ve Ankara) valilik binası merkez olmak üzere $50 \mathrm{~km}, 1$ milyon ile 2 milyon arası nüfuslu kentlerde ise $30 \mathrm{~km}$ yarıçaplı alan olarak yeniden tanımlamıştır. Yasa, Büyükşehir sınırları içindeki yerleşmeleri; ilçe merkezi statüsünde olanları "ilçe belediyeleri " ve belde niteliğinde olanları "ilk kademe belediyeleri" olarak tanımlamış, bu tür yerleşimlerin sınırları dışında kalan yerleşmeler ise "köy" statüsünde kabul edilmiştir.

İstanbul ve Kocaeli il sınırlarının tanımlanan 50 ve $30 \mathrm{~km}$ yarıçaplı alan içine sığıyor olması nedeniyle bu illerde il sınırları içindeki alan yasa gereği bütünüyle Büyükşehir Belediyesinin görev ve yetki alanı olarak tanımlanmıştır.

\subsubsection{6 sayılı Kanun}

10.07.2004 tarihinde kabul edilen 5216 sayılı "Büyükșehir Belediye Kanunu", belediye sınırları içindeki ve bu sınırlara en fazla 10.000 metre uzaklıktaki yerleşim birimlerinin son nüfus sayımına göre toplam nüfusu 750.000 'den fazla olan il belediyelerinin, fizikî yerleşim durumları ve ekonomik geliş̧şşlik düzeyleri de dikkate alınarak, büyükşehir belediyesine dönüştürülmesini öngörmüştür (Madde 4). Yasa, büyükşehir ile bağlı ilçe ve ilk kademe belediyelerinin görev ve yetkilerini yeniden belirlemiş ve özellikle planlama ile ilgili olarak Büyükşehir Belediyesinin yetkilerini artırmıştır.

Yasa Geçici Madde 2 ile büyükşehir belediye sınırlarının; İstanbul ve Kocaeli ilinde il mülkî sınırı; diğer büyükşehir belediyelerinde, mevcut valilik binası merkez kabul edilmek ve il mülkî sınırları içinde kalmak şartıyla, nüfusu 1 milyona kadar olan büyükşehirlerde yarıçapı $20 \mathrm{~km}$, nüfusu $1-2$ milyon arasında olan büyükşehirlerde yarıçapı $30 \mathrm{~km}$, nüfusu 2 milyondan fazla olan büyükşehirlerde yarıçapı $50 \mathrm{~km}$ olan dairenin sınırı olmasını öngörmektedir.

\subsubsection{0 sayılı Kanun}

12.11.2012 tarihinde kabul edilen ve bazı maddeleri ilk yerel seçimlerden (2014) sonra yürürlüğe giren 6360 sayılı "13 ilde Büyükşehir Belediyesi Kurulması ile ilgili Kanun" ülkedeki büyükşehir belediye sayısını 29'a çıkarmıştır. Daha sonra bu yasaya 14.03.2013 tarih ve 6447 sayılı Kanun ile yapılan bir ekleme ile 750.000 nüfusun altında olan Ordu ili de Büyükşehir kabul edilerek (Madde 1) Türkiye'de büyükşehir belediye sayısı 30 olmuştur.

6360 sayılı yasa, ek olarak daha önce 5019 sayılı yasanın İstanbul ve Kocaeli için öngörmüş olduğu il sınırlarına kadar genişleyen belediye sınırı kavramını bütün büyükşehirlere yaygınlaştırmıştır. Bu şekilde büyükşehir olan illerde il sınırları içinde kırsal alan kavramı kalmamış ve en ücra köyler bile kademeli olarak bağlı olduğu ilçe belediyesinin ve büyükşehrin mahallesi statüsünü kazanmıştır.

Diğer taraftan, yasa daha önce "ilçe merkezi" gibi herhangi bir idari statüsü olmadan ilgili nüfus kriterini sağlayan beldelerde kurulmuş olan ilk kademe belediyelerinin de kapatılarak ilgili ilçelere 
bağlı mahalle düzeyine indirilmesini öngörmektedir. 6360 sayılı yasa ayrıca, büyükşehir belediyesi kurulan illerde yerel yönetimin diğer bir ayağı olan İ Özel İdareleri'ni de kaldırmaktadır (Madde 1/5).

\subsection{Kırsal Alan Tanımı ve Kırsal Yerleşme Nüfus Büyüklüğü}

Ülkemizde Belediye kavramı, baştan beri kentsel çevrelerde yerel hizmetlerin yerel seçimle gelen organlar eliyle yerine getirilebilmesi için oluşturulan bir örgütlenme türü olup kırsal alanları kapsamamaktadır. Bu uygulamanın dayanağı, 19.03.1924 yılında kabul edilen 422 sayılı Köy Kanunu'nun "Nüfusu iki binden aşağı yurtlara (köy) ve nüfusu iki bin ile yirmi bin arasında olanlara (kasaba) ve yirmi binden çok nüfusu olanlara (şehir) denir. Nüfusu iki binden aşağı olsa dahi belediye teşkilatı mevcut olan nahiye, kaza ve vilayet merkezleri kasaba itibar olunur. Ve Belediye Kanununa tabidir" (Madde 1) ifadesi olmuş ve 2000'li yıllara kadar belediye teşkilatı kurulabilmesi için gerekli asgari nüfus büyüklüğü 2.000 kişi olarak kabul edilmiştir. Ancak, nüfusu 2.000'den fazla olduğu için belediye teşkilatına sahip olan bu yerleşmeler sosyal ve ekonomik göstergelerinden hareketle uzmanlar tarafından kentsel yerine genellikle yarı - kırsal nitelikte değerlendirilmiştir. Dolayısıyla, başlangıçtaki belediye ve kent tanımlarının bire bir örtüşmesi kabulü de güncel gelişmelere uymaması nedeniyle zaman içinde terk edilmiştir.

Günümüzde belediye ve kent nitelemesi için gerekli asgari nüfus büyüklüğü konusunda uzlaşma yoktur. Şöyle ki;

- 03.07. 2005 tarihinde kabul edilen 5393 sayılı "Belediye Kanunu", "Nüfusu 5.000 ve üzerinde olan yerleşim birimlerinde belediye kurulabilir. il ve ilçe merkezlerinde belediye kurulması zorunludur" (Madde 4) ifadesi ile taban nüfusu 5.000 kişi olarak belirlemektedir.

- Türkiye isstatistik Kurumu (TÜiK) veri tabanında küçük nüfuslu belediyeler arasında ilçe merkezi olmasa bile nüfusu 5.000'den az yerleşimler yer almaktadır. "Belde" olarak anılan bu yerleşmelerden örneğin Isparta'da Merkez İlçe’ye bağlı Kuleönü ve Savköy ile Gönen İlçesi'ne bağlı Güneykent bu tür belediye teşkilatına sahip beldeler olup 2015 yılı nüfusları sırasıyla 2.383, 3.500 ve 2.085 kişidir. Buradan, 5393 sayılı "Belediye Kanunu"nun öngördüğü 5.000 asgari nüfus kriterinin yeni belediyelerin kurulmasında geçerli olup geçmişe dönük uygulanmadığı anlaşılmaktadır.

- Diğer taraftan, gerek 2014 yılında T.C. Gıda, Tarım ve Hayvancılık Bakanlığı'nca hazırlanan “Ulusal Kırsal Kalkınma Stratejisi (UKKS) 2014 - 2020"de (sayfa 7), gerekse de T.C. Kalkınma Bakanlığı tarafından 2014 yılında yayınlanan "Bölgesel Gelişme Ulusal Stratejisi (BGUS) 2014 - 2023"de (sayfa 92) kırsal alan uygulama alanının 20.000 ve daha az nüfusa sahip tüm yerleşimleri kapsadığı görülmektedir.

2006 yılında yapılan "Kırsal Alan Planlaması: Bir Model Önerisi" başlıklı bir çalışma da benzer şekilde, "ülkemizde kırsal alanların tanımlanmasında ve kademelenmesinde kullanılabilecek ve üzerinde fikir birliği olan kapsamlı bir yaklaşım yoktur" saptamasından sonra nüfusu 20 binin altındaki yerleşmeleri "kırsal yerleşme" olarak kabul etmiş bulunmaktadır. Çalışma ayrıca "Nüfus dışında, genel olarak kırsal alanı tanımlamada ifade edilen özellikler(in) az yoğun yerleşme, birincil sektör ağırlıklı üretim ve örgütlülük düzeyi düşük sosyo-kültürel yapı" olduğunu da belirtmektedir (Şenol vd., 2006).

Aradan geçen 10 yıla karşın, ilgili kurum ve kuruluşlarca geniş katıımlı çalışmalar sonunda üzerinde uzlaşılan bir kırsal yerleşim nüfus tabanı kriteri olmadığından günümüz koşullarında, ilçe merkezi veya belediye olsun ya da olmasın, iller ve Büyükşehir belediyelerinin sınırları içinde bulunan 20.000'den az nüfuslu, köy ya da mahalle statüsündeki yerleşmelerin tümü kırsal nitelikte kabul edilebilir.

\subsection{Nüfusun Kentsel / Kırsal Dağılımı}

Türkiye'de nüfusun kentsel ve kırsal yerleşmelere göre dağılımı kentler lehine hızlı bir değişim göstermektedir. Türkiye İstatistik Kurumu (TÜiK) verilerine göre 1927 yılında 13.648 .270 olan toplam nüfusun \% 24.2'si kentsel yerleşmelerde (il ve ilçe merkezleri) yaşarken, 2010 yılında toplam 73.722 .988 nüfus içinde kentsel nüfus oranı \% 76.3 olarak görünmektedir (URL-1). Aynı değerlendirme 2015 yılı için yapıldığında kentsel nüfusun toplam ülke nüfusuna oranı \% 92.1 olarak 
görülmektedir (Çizelge 1). Ancak bu değer 6360 sayılı yasa uygulaması sonucunda büyükşehir belediyesine sahip illerde, merkez ya da çevre ilçelerin sınırları içindeki bütün köylerin mahalle olarak sayılması sonucu olup niteliksel anlamda kentsel / kırsal ayrımını ifade etmemektedir.

Bilindiği üzere planlama literatüründe kentsel ve kırsal kavramlarının tanımı ilgili yerleşimin sosyoekonomik niteliklerine dayandırılır (Kıray, 1972). Bu açıdan bakıldığında, TÜiK verilerinde idari statü olarak ilçe merkezi konumunda olan yerleşimlerin büyük bir bölümünün "yarı kırsal" gibi bir tanımın eksikliği nedeniyle "kentsel" nitelikte değerlendirilmesi durumu bulandırmaktadır. Benzer şekilde, diğer bir grup değerlendirmeye temel alınan yerleşimlerin belediye teşkilatına sahip olmalarının da kentsel yapıyı garantilemediği bilinmektedir. Son olarak, 2014 yılından sonra 6360 sayılı yasa uyarınca 30 ilin sınırları içindeki tüm nüfusun kentsel olarak sayılması da mevcut durumu iyice anlamsızlaştırmıştır.

Yerleşimlerin kentsel / kırsal ayrımının sosyo-ekonomik niteliklere göre yapılması ise ancak özgün bir araştırma sonunda olanaklı görünmektedir. Bugün için anılan hata paylarını göz önünde bulundurmak kaydıyla TÜiK sınıflandırmasını kullanmak yine de kaçınılmaz olmaktadır. Aşağıdaki çizelgede ülkemizdeki nüfus sayımı ve son dönemler için Adrese Dayalı Nüfus Kayıt Sistemi (ADNKS) sonuçları kentsel / kırsal nüfus oranını göstermek üzere 10 yıllık aralıklara göre sunulmaktadır:

Çizelge 1.Türkiye'de Kentsel ve Kırsal Nüfus (TÜiK, 2015)

\begin{tabular}{|l|l|l|l|l|l|}
\hline \multirow{2}{*}{$\begin{array}{l}\text { Yayım } \\
\text { Yılı }\end{array}$} & \multirow{2}{*}{ Toplam Nüfus } & \multicolumn{2}{l}{ il I ilçe Merkezleri } & \multicolumn{2}{l}{ Belde / Köyler } \\
\cline { 3 - 6 } & & Nüfus & $\%$ & Nüfus & $\%$ \\
\hline 1927 & 13.648 .270 & 3.305 .879 & 24.2 & 10.342 .391 & 75.8 \\
\hline 1940 & 17.820 .950 & 4.346 .249 & 24.4 & 13.474 .701 & 75.6 \\
\hline 1950 & 20.947 .188 & 5.244 .337 & 25.0 & 15.702 .851 & 75.0 \\
\hline 1960 & 27.754 .820 & 8.859 .731 & 31.9 & 18.895 .089 & 68.1 \\
\hline 1970 & 35.605 .176 & 13.691 .101 & 38.5 & 21.914 .075 & 61.5 \\
\hline 1980 & 44.736 .957 & 19.645 .007 & 43.9 & 25.091 .950 & 56.1 \\
\hline 1990 & 56.473 .035 & 33.326 .351 & 59.0 & 23.146684 & 41.0 \\
\hline 2000 & 67.803 .927 & 44.006 .274 & 64.9 & 23.797 .653 & 35.1 \\
\hline 2010 & 73.722 .988 & 56.222 .356 & 76.3 & 17.500 .632 & 23.7 \\
\hline $2015 *$ & 78.741 .053 & 72.523 .134 & 92.1 & 6.217 .919 & 7.9 \\
\hline
\end{tabular}

*2010 - 2015 yılları arasında 10 yıl ara olmamasına rağmen 2015 yılı ADNKS değerleri Çizelge 1'de karşılaştırma amacıyla dahil edilmiştir.

Çizelge 1'den, ülkemizde kentleşmenin özellikle 1950 yılından sonra hız kazandığı ve ilk kez 1990 yılında kentlerde yerleşen nüfusun kırsalda yaşayan nüfusu geçtiği görülmektedir. Gerçekte kentsel / kırsal nüfus eşitlenmesi 10 yıllık aralık kabulü nedeniyle Çizelge 1'de gösterilmeyen 1985 sayımında \% 53 oran ile gerçekleşmiş bulunmaktadır. Çizelge özellikle kırsal alandan kentlere göçün tetiklediği kentsel nüfus artışının ilerleyen yıllarda tempo yükselttiğini ve 20. Yüzyıl sonunda 2000 yılı değerlerine göre \% 64.9 ile artık kentli nüfusun ağırlığını duyurduğunu göstermektedir. 2015 yılında \% 100'e yaklaşmış kentsel nüfus oranı ise 6360 sayılı yasanın yürürlüğe girmesiyle büyükşehir sınırlarında oluşan değişikliğin sonucu olup daha önce belirtildiği üzere nüfusun kentsel / kırsal ayrımı konusunda yanıltıcıdır. Yanılgı, yasanın büyükşehir belediye sınırları içindeki kırsal nitelikli yerleşmeleri de mahalle saymasından kaynaklanmakta olup kentsel / kırsal nüfus dağılımı konusunda fazla anlam ifade etmemektedir. Bu uygulamadan kaynaklanan sorunlar bu yazının tartışacağı temel konuları oluşturmaktadır. 
Burada ara sonuç olarak, Türkiye'de kentleşmenin bugün gelinen noktasında nüfusun daha net ve hata paylarından arındırılmış bir kentsel ve kırsal olarak ayrımına hala ihtiyaç olduğu görülmektedir. Bu amaca yönelik olarak yerleşmelerin niteliksel ayrımından hareketle bir tanımlama yapılması ve TÜiK'in verilerini bu çerçevede işlemden geçirmesi gündemdeki görevler arasındadır.

\subsection{Türkiye'de Büyükşehirler}

6360 sayılı yasa uygulaması ve TÜik 2015 yılı verilerine göre bugün Türkiye'de 30 adet Büyükşehir Belediyesi bulunmaktadır. Bu belediyelerin Büyükşehir oluş yılları, toplam nüfusları, toplam ve merkezdeki toplu yerleşimi (anakent) oluşturan ilçe sayıları ile anakentte yerleşik nüfusun büyüklüğü ve toplam nüfus içindeki payı iller bazında ayrımlı olarak aşağıda Çizelge 2'de sunulmaktadır.

6360 sayılı yasa, il sınırları içinde bulunan tüm yerleşmeleri büyükşehir belediyesinin ilçe ve mahalleleri olarak kabul ederken zımnen hepsini kentsel nitelikli yerleşimler olarak ta kabul etmiş olmaktadır. Oysa bahse konu il ve/veya büyükşehir belediye sınırları içindeki yerleşmelerin büyük bölümü sosyo-ekonomik göstergeler bakımından bugün hala daha kırsal karakterli durumdadır. Aşağıdaki çizelge hazırlanırken, bu özellik dikkate alınmış ve illerde merkezdeki anakent yerleşmesini oluşturan merkez ilçeler uzay görüntülerinden ayrıntılı bir değerlendirme yapılarak belirlenmiş ve nüfusları ayrı bir grup halinde toplanmıştır. Bu yaklaşım ile 6360 sayılı yasada öngörülen büyükşehir coğrafyasına alternatif olarak büyükşehirlerdeki gerçek nüfus yığılmasının il toplamı içindeki payı ortaya konulmak istenmiştir.

Bu yaklaşım da birkaç nedene dayalı olarak hata payı içermektedir. Öncelikle, illerin bir bölümünde büyükşehrin anakent bütünlüğü dışında kalmakla birlikte önemli boyutta nüfus barındıran bir dizi ilçe merkezinin gerçek anlamda kentsel niteliklere sahip olmalarına karşın (Örneğin Tarsus (Mersin), Nazilli (Aydın), İskenderun (Hatay), Akhisar (Manisa), vb.) nüfuslarının çizelge dışında kalmalarıdır. Diğer taraftan, TÜik verilerinde büyükşehir belediyelerinin merkezdeki anakenti oluşturan ilçelerinin belediye nüfusları ilçe sınırları içindeki kırsal yerleşmeleri de içermektedir. Bu sorunun aşılması ve daha net bir kentsel / kırsal nüfus oranı elde olunması TÜik /ADNKS veri tabanında ilçeler ve mahalleler düzeyinde yapılacak daha ayrıntılı bir çalışma gerektirdiğinden bu yazıda girilememiştir.

Çizelge 2. Türkiye'de Büyükşehir Belediyeleri, ilan yılları, toplam ilçe sayıları, anakent ilçeleri ve sayıları ile 2015 nüfusları (TÜiK, 2015)

\begin{tabular}{|c|c|c|c|c|c|c|c|c|c|}
\hline \multirow[b]{2}{*}{$\begin{array}{l}\text { Sira } \\
\text { No. }\end{array}$} & \multicolumn{2}{|c|}{ Büyükşehir } & \multirow[b]{2}{*}{$\begin{array}{c}2015 \text { Nüfusu } \\
\left({ }^{* *}\right)\end{array}$} & \multirow{2}{*}{$\begin{array}{c}\text { Toplam } \\
\text { İlçe } \\
\text { Sayısı }\end{array}$} & \multicolumn{5}{|c|}{ Merkezdeki Toplu Yerleşim (Anakent) } \\
\hline & Adı & $\begin{array}{l}\text { İlan } \\
\text { Yılı }\end{array}$ & & & $\begin{array}{l}\text { illçe } \\
\text { Sayısı }\end{array}$ & İlçe Adı & $\begin{array}{l}\text { İlçe Nüf. } \\
(* * *)\end{array}$ & $\begin{array}{c}\text { Toplam } \\
\text { Kentsel N. }\end{array}$ & $\begin{array}{c}\% \\
(* * * *)\end{array}$ \\
\hline 1 & İstanbul $(*)$ & 1984 & 14.657 .434 & 39 & 39 & Tümü & & 14.657.434 & 100 \\
\hline \multirow[t]{9}{*}{2} & \multirow[t]{9}{*}{ Ankara } & \multirow[t]{9}{*}{1984} & \multirow[t]{9}{*}{5.270 .575} & \multirow[t]{9}{*}{25} & \multirow[t]{9}{*}{9} & Altındağ & 363.687 & \multirow[t]{9}{*}{ 4.707.421 } & \multirow[t]{9}{*}{89} \\
\hline & & & & & & Çankaya & 922.536 & & \\
\hline & & & & & & Etimesgut & 527.959 & & \\
\hline & & & & & & Gölbaşı & 122.288 & & \\
\hline & & & & & & Keçiören & 889.876 & & \\
\hline & & & & & & Mamak & 607.878 & & \\
\hline & & & & & & Pursaklar & 133.961 & & \\
\hline & & & & & & Yenimahalle & 506.950 & & \\
\hline & & & & & & Sincan & 632.286 & & \\
\hline \multirow[t]{11}{*}{3} & \multirow[t]{11}{*}{ İzmir } & \multirow[t]{11}{*}{1984} & \multirow[t]{11}{*}{4.168 .415} & \multirow[t]{11}{*}{30} & \multirow[t]{11}{*}{11} & Balçova & 78.121 & \multirow[t]{11}{*}{2.891 .492} & \multirow[t]{11}{*}{69} \\
\hline & & & & & & Bayraklı & 312.263 & & \\
\hline & & & & & & Bornova & 435.162 & & \\
\hline & & & & & & Buca & 470.768 & & \\
\hline & & & & & & Çiğli & 182.349 & & \\
\hline & & & & & & Gaziemir & 132.365 & & \\
\hline & & & & & & Güzelbahçe & 29.774 & & \\
\hline & & & & & & Karabağlar & 477.238 & & \\
\hline & & & & & & Karşıyaka & 333.250 & & \\
\hline & & & & & & Konak & 375.490 & & \\
\hline & & & & & & Narlıdere & 64.712 & & \\
\hline
\end{tabular}


Çizelge 2. Türkiye'de Büyükşehir Belediyeleri, ilan yılları, toplam ilçe sayıları, anakent ilçeleri ve sayıları ile 2015 nüfusları (Devam) (TÜiK, 2015)

\begin{tabular}{|c|c|c|c|c|c|c|c|c|c|}
\hline \multirow[t]{3}{*}{4} & \multirow[t]{3}{*}{ Bursa } & \multirow[t]{3}{*}{1987} & \multirow[t]{3}{*}{2.842 .547} & \multirow[t]{3}{*}{17} & \multirow[t]{3}{*}{3} & Nilüfer & 397.303 & \multirow[t]{3}{*}{1.867 .681} & \multirow[t]{3}{*}{65} \\
\hline & & & & & & Osmangazi & 826.742 & & \\
\hline & & & & & & Yıldırım & 643.681 & & \\
\hline \multirow[t]{4}{*}{5} & \multirow[t]{4}{*}{ Antalya } & \multirow[t]{4}{*}{1993} & \multirow[t]{4}{*}{2.288 .456} & \multirow[t]{4}{*}{19} & \multirow[t]{4}{*}{4} & Aksu & 68.496 & \multirow[t]{4}{*}{1.197 .948} & \multirow[t]{4}{*}{52} \\
\hline & & & & & & Kepez & 497.242 & & \\
\hline & & & & & & Konyaaltı & 154.920 & & \\
\hline & & & & & & Muratpaşa & 477.290 & & \\
\hline \multirow[t]{4}{*}{6} & Adana & 1986 & 2.183 .167 & 15 & 4 & Çukurova & 359.315 & 1.717 .473 & 78 \\
\hline & & & & & & Sarıçam & 150.425 & & \\
\hline & & & & & & Seyhan & 788.722 & & \\
\hline & & & & & & Yüreğir & 419.011 & & \\
\hline 7 & Konya & 1987 & 2.130 .544 & 31 & 3 & Karatay & 302.392 & 1.250 .482 & 58 \\
\hline & & & & & & Meram & 343.384 & & \\
\hline & & & & & & Selçuklu & 604.706 & & \\
\hline 8 & Gaziantep & 1987 & 1.931 .836 & 9 & 2 & Şahinbey & 870.493 & 1.597 .324 & 82 \\
\hline & & & & & & Şehitkamil & 726.831 & & \\
\hline 9 & Şanlıurfa & 2012 & 1.892 .320 & 13 & 3 & Eyyübiye & 368.293 & 865.769 & 45 \\
\hline & & & & & & Haliliye & 364.946 & & \\
\hline & & & & & & Karaköprü & 132.530 & & \\
\hline 10 & Mersin & 1993 & 1.745 .211 & 13 & 4 & Akdeniz & 272.366 & 970.626 & 55 \\
\hline & & & & & & Toroslar & 171.837 & & \\
\hline & & & & & & Mezitli & 285.971 & & \\
\hline & & & & & & Yenişehir & 240.452 & & \\
\hline 11 & Kocaeli & 1993 & 1.780 .055 & 12 & 7 & Çayırova & 117.230 & 1.330 .639 & 74 \\
\hline & & & & & & Darıca & 182.230 & & \\
\hline & & & & & & Derince & 136.742 & & \\
\hline & & & & & & Dilovası & 46.099 & & \\
\hline & & & & & & Gebze & 350.115 & & \\
\hline & & & & & & İzmit & 347.074 & & \\
\hline & & & & & & Körfez & 151.149 & & \\
\hline 12 & Diyarbakır & 1993 & 1.654 .196 & 17 & 4 & Bağlar & 375.312 & 1.008 .848 & 60 \\
\hline & & & & & & Kayapınar & 308.994 & & \\
\hline & & & & & & Sur & 117.698 & & \\
\hline & & & & & & Yenişehir & 206.844 & & \\
\hline 13 & Hatay & 2012 & 1.533 .507 & 15 & 2 & Antakya & 360.652 & 500.749 & 32 \\
\hline & & & & & & Defne & 140.097 & & \\
\hline 14 & Manisa & 2012 & 1.380 .366 & 17 & 2 & Şehzadeler & 168.695 & 380.368 & 27 \\
\hline & & & & & & Yunusemre & 211.673 & & \\
\hline 15 & Kayseri & 1988 & 1.341 .056 & 16 & 3 & Kocasinan & 388.364 & 1.074 .325 & 80 \\
\hline & & & & & & Melikgazi & 548.028 & & \\
\hline & & & & & & Talas & 137.933 & & \\
\hline 16 & Samsun & 1993 & 1.279 .884 & 17 & 4 & Atakum & 169.809 & 588.074 & 45 \\
\hline & & & & & & Canik & 96.541 & & \\
\hline & & & & & & İlkadım & 321.714 & & \\
\hline 17 & Balıkesir & 2012 & 1.186 .688 & 20 & 2 & Karesi & 173.386 & 347.072 & 29 \\
\hline & & & & & & 6 Eylül & 173.686 & & \\
\hline 18 & K.Maraş & 2012 & 1.096 .610 & 11 & 2 & Dulkadiroğlu & 218.067 & 603.020 & 54 \\
\hline & & & & & & 12 Şubat & 384.953 & & \\
\hline 19 & Van & 2012 & 1.096 .397 & 13 & 3 & Edremit & 118.786 & 554.002 & 50 \\
\hline & & & & & & İpekyolu & 285.272 & & \\
\hline & & & & & & Tuşba & 149.944 & & \\
\hline 20 & Aydın & 2012 & 1.053 .506 & 17 & 1 & Efeler & 277.466 & 277.466 & 26 \\
\hline 21 & Denizli & 2012 & 993.442 & 19 & 2 & Merkezefendi & 280.341 & 611.341 & 61 \\
\hline & & & & & & Pamukkale & 331.000 & & \\
\hline
\end{tabular}


Çizelge 2. Türkiye'de Büyükşehir Belediyeleri, ilan yılları, toplam ilçe sayıları, anakent ilçeleri ve sayıları ile 2015 nüfusları (Devam) (TÜiK, 2015)

\begin{tabular}{|c|c|c|c|c|c|c|c|c|c|}
\hline 22 & Sakarya & & 953.181 & 16 & 1 & Adapazarı & 269.079 & 269.079 & 28 \\
\hline 23 & Tekirdağ & 2012 & 937.910 & 11 & 1 & Süleymanpaşa & 187.727 & 187.727 & 20 \\
\hline 24 & Muğla & 2012 & 908.877 & 13 & 1 & Menteşe & 105.860 & 105.860 & 11 \\
\hline \multirow[t]{2}{*}{25} & \multirow[t]{2}{*}{ Eskişehir } & & \multirow[t]{2}{*}{826.716} & \multirow[t]{2}{*}{14} & \multirow[t]{2}{*}{2} & Odunpazarı & 383.523 & \multirow[t]{2}{*}{717.076} & \multirow[t]{2}{*}{86} \\
\hline & & & & & & Tepebaşı & 333.553 & & \\
\hline 26 & Mardin & 2012 & 796.591 & 10 & 1 & Artuklu & 156.660 & 156.660 & 19 \\
\hline 27 & Malatya & 2012 & 772.904 & 13 & 1 & Battalgazi & 301.483 & 301.483 & 39 \\
\hline 28 & Trabzon & 2012 & 768.417 & 18 & 1 & Ortahisar & 320.225 & 320.225 & 41 \\
\hline \multirow[t]{3}{*}{29} & \multirow[t]{3}{*}{ Erzurum } & \multirow[t]{3}{*}{1993} & \multirow[t]{3}{*}{762.321} & \multirow[t]{3}{*}{21} & \multirow[t]{3}{*}{3} & Aziziye & 53.506 & \multirow[t]{3}{*}{412.326} & \multirow[t]{3}{*}{54} \\
\hline & & & & & & Palandöken & 167.892 & & \\
\hline & & & & & & Yakutiye & 190.928 & & \\
\hline \multirow[t]{2}{*}{30} & Ordu & 2013 & 728.949 & 19 & 1 & Altınordu & 202.310 & 202.310 & 27 \\
\hline & TOPLAM & & 60.962 .078 & & & & & 41.672 .300 & 68 \\
\hline
\end{tabular}

(*) Özgün coğrafi nitelikleri ve merkezden uzak kırsal alanı olmaması nedeniyle yalnızca İstanbul çizelgede farklı şekilde değerlendirilmiş ve il nüfusu (ilgili yasaya paralel olarak) tümüyle kentsel karakterli varsayılmıştır.

$(* *) 6360$ sayılı yasa gereği il nüfusudur.

$\left.{ }^{* *}\right)$ TÜiK verileri ilçe sınırları içindeki nüfus ile belediye nüfuslarını özdeş olarak göstermektedir.

$\left({ }^{* * *}\right)$ Büyükşehir merkezindeki ilçelerde yaşayan nüfusun toplama oranıdır.

Çizelge 2'den Türkiye'de toplam sayısı 30 olan Büyükşehir Belediye (aynı zamanda il) sınırları içinde yaşayan nüfus toplamı 2015 yılı Tüik verilerine göre 60.962.078 kişi olup bunun 41.672 .300 'inin büyükşehrin merkezini oluşturan anakentlerde yerleştiği görülmektedir. Ülkedeki kentleşme düzeyinin en yoğun olduğu bu tür anakent yerleşimlerinde yaşayan nüfusun büyükşehir (il) sınırları içindeki toplama oranı \% 68 olarak ortaya çıkmaktadır. Diğer taraftan, 2015 yılı Türkiye toplam nüfusu 78.741 .053 olduğuna göre Büyükşehir sınırları içinde yaşayan nüfusun (60.962.078) ülke toplamına oranı \% 77, büyükşehirlerin merkezindeki ana kentlerde yaşayan nüfusun (41.672.300) ülke toplamına oranı ise $\% 53$ olmaktadır. Bu sonuçlar, kentsel nüfusun ağırlıklı bölümünün büyükşehirlere yığıldığını ortaya koymaktadır.

Diğer taraftan, Türkiye'de yürürlükteki mevzuat nedeniyle büyükşehir statüsüne sahip belediyelerin merkezi yerleşmesi olan anakentlerin bir bölümü planlamada "büyükşehir" kavramının karşılığı olan "metropol" niteliğinden uzaktır. Bu bildirinin tartışma konusu dışında olmakla birlikte, metropoliten kent için taban nüfus kabaca 2 milyon kişi olarak kabul edilirse bu ölçülere Çizelge 2'deki kentlerden yalnızca İstanbul, Ankara ve İzmir uymaktadır. Bunların dışında kalan 20 (büyükşehir belediyesine sahip) kentler ile 6360 sayılı yasanın kapsamı dışında kalan diğer il merkezleri ve nüfusları 100.000 'den fazla ilçe merkezleri "kentsel“nitelikli yerleşmeler olarak değerlendirilebilir.

\subsection{Büyükşehir Sınırları İ̧̧inde Kırsal Yerleşimler}

Türkiye'de kırsal alana kamu altyapı hizmetleri daha önce 09.05.1985 tarihinde kabul edilen 3202 sayılı “Köy Hizmetleri Genel Müdürlüğü Teşkilat ve Görevleri Hakkında Kanun" kapsamında Tarım, Orman ve Köy İşleri Bakanlığına bağlı Köy Hizmetleri Genel Müdürlüğü tarafından sağlanırken bu kurum 13.05.2005 tarih ve 5286 sayılı kanunla kaldırılmış, görev ve yetkileri, (i̇stanbul ve Kocaeli illeri dışında) taşınmaz malları, araç, ekipman ve elemanları ile birlikte İ Özel İdareleri'ne devredilmiştir.

2012 yılında yasalaşmakla birlikte maddelerinin büyük bölümü (yerel seçimlerden sonra) 2014 yılında uygulamaya geçen 6360 sayılı yasa ile Büyükşehir Belediyesi olan illerde kırsal alana hizmet görevi Büyükşehir Belediyelerine aktarılmıştır. Günümüzde kırsal alana hizmet görev ve yetkisi, ülkedeki 81 ilin 30'unda Büyükşehir Belediyeleri, kalan 51 ilde İ Özel İdarelerine ait bulunmaktadır.

6360 sayılı yasanın etkilerini mülki idare açısından inceleyen bir çalışma, en önemli sonucun "taşra yönetimi, özellikle mülki idare bakımından il özel idaresi ve köylerin kapatılması (ve) aynı kapsamda, il özel idare ve köylere hizmet götürme bütçeleri gibi iki kaynak kullanım aracından yoksun kalmak, mülki idarenin taşradaki ağırlığının sembolik düzeye inmesi, diğer bir ifadeyle, sınırlı valiliğe doğru evrilme" olarak değerlendirmektedir (Apan, 2016). 
6360 sayılı Kanunun etkileri mülki idaredeki değişiklikler ile sınırlı değildir. Yasanın uygulama bölgesinde yer alan kentsel ve kırsal yerleşmelerin karşılıklı ilişkileri, görev ve yükümlülükleri, gelir ve giderleri ile hizmet teminine yönelik prosedürler de değişme göstermektedir.

Türkiye'de geçmişte de kısmen var olmakla birlikte daha sınırlı boyutta iken, 6360 sayılı yasa ertesinde büyükşehir belediye sınırları içindeki kırsal alan konusunda yaşanan gelişmeler ve ortaya çıkan sorunlar şöyle özetlenebilir;

\subsubsection{Yasanın Hazırlık ve Geçiş Süreci Olmadan Uygulanması}

6360 sayılı Kanun'un yasalaşması ile görev değişikliğine ilişkin maddelerinin uygulanması arasında 2 yıllık sürede ilgili kurumlar (il Özel İdareleri ile büyükşehir belediyeleri) arasında bu önemli görev devri için herhangi bir hazırlık yapılmadığı, bunun yerine, görev tesliminin 2014 yılındaki yerel seçim sonuçları belli olduktan sonra kısa süre içinde hızlı bir şekilde gerçekleştirilmiştir. Yasayla, büyükşehir belediyeleri daha geniş bir alanda artan ve çeşitlenen hizmet görevlerini aynı altyapı ile götürmek gibi bir sorunla karşı karşıya kalmışlardır. Özellikle yeni kurulan büyükşehir belediyelerinde geçmişten gelen oturmuş bir yapı ve hizmet pratiği de olmadığından sorun da daha büyük olmuştur.

\subsubsection{Organizasyon eksikleri}

Diğer taraftan, kırsal kesime hizmet görevinin eski sahibi il Özel İdareleri'nin kurumsal hafızası ve arşivinin de büyükşehir belediyelerine sistematik bir biçimde aktarılmadığı gözlenmiştir. Yapılan aktarımların, çoğu örnekte, daha önce ilgili bilgi, belge ve dokümanları üreten ve/veya kullanan görevlilerin katılımı olmadan ve ortaklaşa bir çalışma ile yeni adresteki sorumlulara gerekli bilgi ve deneyim paylaşımı olmaksızın yapılınca arşivdeki bilgilerin önemli bir bölümünün kaybı kaçınılmaz olmuş ve büyükşehir belediyeleri kırsal alana hizmet götürmede neredeyse sıfırdan işe başlamışlardır.

\subsubsection{Uygulamada Görülen Sorunlar}

6360 sayılı yasanın uygulanması ülkede özellikle belediye ve kırsal alan konularında köklü bir değişiklik getirmektedir. Bu konuda, 2015 yılında Güneydoğu Anadolu Bölgesi'nde "Yerel Yönetim Personeli Kapasite Artırımı Projesi" kapsamında gerçekleştirilen bir arazi çalışmasının sonuç raporunda aşağıdaki hususlar belirlenmiş bulunmaktadır:

- Yasa, il Özel İdareleri kapatılırken görev ve sorumluluklarına ek olarak kurumun mevcut arsa, tesis, makine, ekipman ve elemanlarının da belediyelere devrini öngörmüş bulunmaktadır. Ancak, merkezi yönetim birimleri anılan kapasitenin önemli bir bölümünü kendisine ayırdıktan sonra gerçekleştirmiş görünmektedir.

- Belde belediyeleri kapatılıp mahalle statüsüne indirilmektedir. Bir bölümü uzun belediyecilik geçmişine de sahip olan belde belediyelerinin kapatılarak mahalle düzeyine indirgenmesi ilgili yerleşimlerin sakinlerinde tepkilere neden olmaktadır.

- II sınırlarına dayanan geniş alanda mahalle haline gelen köyler ile sokak statüsüne geçen mezralarda yaşayan seçmenlerin kentsel merkezlerde yerleşik nüfusa eşdeğer hizmet taleplerine kırsal çevre ile uyumlu belediye hizmeti götürmek,

- Görev ve yetki alanı genişlerken daha önceden herhangi bir birikime sahip olunmayan uzak ve kırsal bölgelere de hizmet sunumu için anlayış, yaklaşım ve teşkilatlanma değişikliği ile yeni çalışma yöntemleri ve ekip oluşturma ihtiyacı,

- Genişlemiş hizmet alanına karşın 6360 sayılı Kanun büyükşehir kapsamındaki ilçe belediyeleri gelirlerinin \% 40'ını büyükşehir belediyesine aktarımasını gerektirdiğinden gelirleri düşmüştür,

- (illçe belediyelerine ait) Yol, su ve kanalizasyon, mezarlık gibi görevlerin bir bölümü büyükşehir belediyesine aktarılması nedeniyle görevleri azalırken paralelinde gelirlerinin de \% 40 oranında azalması bütçe sorununu artırmıştır, 
- Büyükşehir - ilçe belediyeleri arasındaki görev ve sorumluluk paylaşımı ilçedeki vatandaşlar tarafından tam bilinemediği için devredilmiş görevler (özellikle merkeze uzak yerlerde yine) ilçe belediyelerinden talep edilmektedir,

- Kurum fetişizmi ve yönetici egoları nedeniyle büyükşehir belediyesi ile (ilçe) belediyeleri arasında tam bir işbirliği ve koordinasyon sağlanmasında güçlük çekilmektedir (GAP Bölge Kalkınma İdaresi, 2016).

\subsubsection{Yasal Mevzuat ile ilgili Sorunlar}

Ülkemizde yerleşme ile ilgili konuların temel dayanağı olan 03.05.1985 tarihinde kabul edilen 3194 sayılı "İmar Kanunu", "belediye ve mücavir alan sınırları içinde ve dışında kalan yerlerde yapılacak planlar ile inşa edilecek resmi ve özel bütün yapılar" (Madde 2) ifadesi ile kentsel ve kırsal ayrımı gözetmese de eki yönetmelikler ve uygulama prosedürleri, ağırlıklı olarak sorunların ortaya çıktığı kentler ve yakın çevrelerine yönelik olarak hazırlanmıştır. Zaman içinde uygulamada görülen sorunlardan hareketle yapılan değişikliklerin de hep kentsel yerleşimler dikkate alınarak kurgulandığı görülmektedir.

Diğer taraftan, 6360 sayılı yasa Türkiye'deki 30 ilde kentsel ve kırsal yerleşim kavramı ile belediye hizmetlerinin nitelik ve niceliğini önemli ölçüde değiştirirken yasanın uygulanma sürecine destek olacak herhangi bir yaklaşım, görüş, yorum ve yönlendirme getirilmemiş, bu amaca yönelik özel çalışmalar yapılmamıştır. Bu durumda, çalışma alanı genişleyen büyükşehir ve ilçe belediyeler yasadan önce kentsel ortam ve çevreye uygun kurgulanmış hizmetleri kırsal çevrede de tekrarlamak durumunda kalmaktadır. Bu konuda yaygın olarak uygulanan hizmet biçimi, ilçe merkezlerinde büyükşehir belediyesine ait bir hizmet biriminin tesisi olmaktadır. Öncelikle içme suyu ücretleri ile çevre vergisi toplama hizmeti gören bu birimin gerektiğinde büyükşehirden altyapı (yol, su, kanalizasyon, vb) hizmetleri için gelen ekiplerce de irtibat amacıyla kullanıldığı görülmektedir.

GAP Bölge Kalkınma İdaresi'nin anılan “Ĕgitim İhtiyaç Analizi ve Eğitim Eylem Planı” sonuç raporunda bu konuda aşağıdaki tespitler yapılmaktadır:

- II sınırları içindeki köyler de belediyelerin mahalleleri haline getirilmektedir. Yasaya uygun olarak il sınırları içinde en ücra noktada yer alan ve tümüyle kırsal niteliğe sahip köylerin bile ilgili ilçe belediyelerin mahallesi haline dönüşmesi, kentsel çevrelere hizmet götürmek üzere tasarlanmış belediye kavramında uyum güçlükleri yaratmaktadır.

- Yakın geçmişte gerçekleşen ve herhangi bir geçiş süreci öngörülmeden yürürlüğe giren bu köklü idari değişikliğin büyükşehir belediyelerine getirdiği sorunlar arasında; Bir bölümü il merkezindeki yoğun kentsel yerleşimi oluşturan merkez ilçe belediyesi, diğer bölümü ise merkezden ayrı bağımsız kentsel yerleşime sahip çevre ilçe belediyesi arasında uyumlu bir belediye hizmetini gerçekleştirecek iş bölümü ve koordinasyonun sağlanması,

- Büyükşehir ve ilçe belediyeleri arasındaki görev ve yetki paylaşımının tek bir yasa ile belirlenmek yerine farklı zamanlarda yasalaşmış çeşitli kanunlar [3030 (27.06.1984), 5019 (11.12.2003), 5216 (10.07.2004) ve 6360 (11.12.2012)] tarafından karmaşık bir şekilde belirleniyor olması bulunmaktadır (sayfa 24).

\subsubsection{Planlama Sorunları}

6360 sayılı yasadan önce büyükşehrin merkezindeki anakente örneğin $100 \mathrm{~km}$, ilçe merkezine $25 \mathrm{~km}$ uzak bir konumda yer alan ve çoğunlukla nüfus kaybeden bir "köy" 2014 yılında büyükşehir belediye sınırları içinde "mahalle" statüsüne geçtiğinde yaşanan başlıca gelişmeler şöyledir;

- Uygulamadan önce "Plansız Alanlar İmar Yönetmeliği" çerçevesinde "belediye ve mücavir alan sınırları içinde ve dışında kalan ve plânı bulunmayan alanlarda" (Madde 1) kısmen daha hızlı ve pratik çözümler getirilebilen kırsal nitelikli yerleşimler 6360 sayılı yasa nedeniyle, büyükşehir belediye sınırları içine yönelik hazırlanan çeşitli ölçeklerdeki imar planları (özellikle Çevre 
Düzeni Planı) nedeniyle anakent merkezindeki tümüyle kentsel bir mahalle ile aynı prosedüre uymak durumunda kalmaktadır.

- Bu konuda, 3194 sayılı Imar Kanunu’nda yapılan bir esneklik sorunu kısmen hafifletir durumdadır. Şöyle ki; 2013 yılında yasanın Madde 8'e eklenen hükümlerden "ü" şıkkı "Büyükşehir belediyesi sınırının il sınırı olması nedeniyle mahalleye dönüşen, nüfusu 5.000'in altında kalan ve kırsal yerleşim özelliği devam eden yerlerdeki uygulamalar, büyükşehir belediye meclisince aksine bir karar alınmadıkça, uygulama imar planı yapılıncaya kadar 27 nci madde hükümlerine göre yürütülür" şeklindedir (Ek: 12/7/2013-6495/73 md.) Yasanın ilgili 27. maddesi ise "Belediye ve mücavir alanlar dışında köylerin köy yerleşik alanlarında, civarında ve mezralarda yapılacak konut, entegre tesis niteliğinde olmayan ve imar planı gerektirmeyen tarım ve hayvancılık amaçı yapılar ......için yapı ruhsatı aranmaz. Ancak etüt ve projelerinin valilikçe incelenmesi, muhtarlıktan yazılı izin alınması ve bu yapıların yöresel doku ve mimari özelliklere, fen, sanat ve sağlık kurallarına uygun olması zorunludur" denilmektedir (Madde 27 - Değişik: 12/7/2013-6495/73 md.). Görüleceği üzere, mevzuatta esneklik "uygulama imar planı yapılıncaya kadar" tanınmış olup daha sonra olağan yasal prosedüre dönülmektedir.

- Bunun yanında, 3194 sayılı İmar Kanunu'na dayalı olarak çıkarılan ve 14.06.2014 tarih ve 29030 sayılı Resmi Gazete'de yayınlanarak yürürlüğe giren "Mekansal Planlar Yapım Yönetmeliği" "her tür ve ölçekteki mekânsal planlar ile bu planlara ilişkin revizyon, ilave, değişikliklerin yapılmasına ve incelenmesine, mekânsal planlar ile özel amaçlı plan ve projelere yönelik usul ve esasları kapsar" ifadesi ile yerleşmelerin kentsel / kırsal niteliklerine göre farklılaşabilecek planlama süreçlerinin önünü kapatmıştır.

Mekânsal Planlar Yapım Yönetmeliği, daha önce kent ve yakın çevresi için hazırlanan 1 / 25.000 ölçekli planların tanımlandığı 11/11/2008 tarih ve 27051 sayılı Resmî Gazete'de yayımlanan "Çevre Düzeni Planlarına Dair Yönetmelik"i yürürlükten kaldırıp (Madde 38 / 2) ilgili ölçeği "Nazım Plan" kapsamına alırken "Plan kademelenmesi uyarınca il bütününde yapılan çevre düzeni planları, yürürlükteki bölge veya havza düzeyindeki çevre düzeni planının genel kararlarına aykırı olmamak kaydıyla hazırlanı" dolaylı ifadesi ile il bütününde Çevre Düzeni Planı (ÇDP) hazırlanmasını gündeme getirmiştir (Madde 6/4). Bu madde uzantısında T.C. Çevre ve Şehircilik Bakanlığı; İstatistiki Bölge Birimleri Sınıflandırması (IBBS) Düzey 2 için T.C. Kalkınma Bakanlığı'nca hazırlanan Mekânsal Stratejik Planlardan hareketle her il ve büyükşehir belediyesi 1/100.000 ölçekte Çevre Düzeni Planlarını hazırlamaktadır.

Bu konuda öne çıkan bir sorun, Çevre Düzeni Planlarının ilgili belediye tarafından tartışlıp görüş verilmesi ve kabulü ya da bizzat hazırlanması aşamasında büyükşehrin (ilin) geleceğe yönelik vizyonu belirlenirken Büyükşehir Belediye Meclisi'nin tutumu olmaktadır. Mecliste ilçeler nüfusları oranında temsil edildiği için genellikle anakenti oluşturan ilçelerin ağırlığı olmakta ve kentin gelecekte anakent ve çevre ilçeleri arasında daha dengeli bir gelişme ve nüfus dağılımına yönelik alternatif bir yaklaşım çoğu örnekte kabul edilmemektedir. Bunun sonucu olarak, merkezde nüfus yığılmasına alternatif dengeli gelişme politikaları yerine geçmişten bugüne süregelen trendin uzantısında merkezdeki anakentlerde yoğunlaşmayı artıran politikalar tercih edilmektedir.

- Yönetmeliğe EK - 2 olarak hazırlanan "Farklı Nüfus Gruplarında Asgari Sosyal ve Teknik Altyapı Alanlarına îlişkin Standartlar ve Asgari Alan Büyüklükleri Tablosu"nda yerleşme alanlarının nüfus büyüklüklerine göre artan asgari standartlar verilmektedir. Kentlerin nüfusları büyüdükçe, diğer bir ifade ile kentleşme düzeyi arttıkça daha geniş sosyal donatı ve teknik altyapı alanları istenmesi mantıklı ve olumlu bir yaklaşım olarak değerlendirilmektedir. Ancak Ek - 2 tablosunda kentler nüfus gruplarına göre sınırlandırılırken en düşük grubun 0-75.000 olarak belirlenmiş olması yarı kırsal ve kırsal nitelikli yerleşimlerin göz ardı edildiğini ve tablonun yalnızca kentler dikkate alınarak hazırlandığını göstermektedir. 
Buna göre, örneğin büyükşehir belediyesi statüsünde olan Antalya ili'nde 2010 (TÜiK 2015 yılı verilerinde ilçe toplam nüfusları ile ilçe merkezi nüfusları ayrımı olmadığından 2010 yılı verileri kullanılmıştır) yılı verilerine göre 90.000 nüfuslu (Örneğin Manavgat) ve 20.000 nüfuslu (örn. Kemer) kentler ile 3.000 nüfuslu bir yarı kırsal yerleşim (Örneğin Akseki) ve 600 nüfuslu bir köyde planlama yapılırken (eğitim, sağlık, sosyo-kültürel, açık ve yeşil alanlar vb. donatı tesisleri) için aynı standartların (kişi başına $\mathrm{m}^{2}$ ve asgari alan büyüklüğü olarak) sağlanması zorunlu tutulmaktadır.

- İmar mevzuatında, anılan yerleşim gruplarındaki kentsel, yarı - kırsal ve kırsal nitelikli yerleşimler için öngörülen planlama süreçleri de standart olup aynı etapları içermektedir. Yalnızca yerleşimlerin seçilen plan dönemi sonu için tahmin edilen nüfus büyüklüğü ve kaplayacağı alan genişliğine (hektar) göre müellif plancının yeterlilik grubu değişmektedir. Ancak planlama alanı büyükşehir belediye sınırları içinde olunca en az 750.000 nüfus nedeniyle en yüksek " $A$ " grubu müellif zorunlu olacağından o maddenin de geçerliliği kalmamakta ve büyükşehir sınırları içindeki en ücra konumdaki (Örneğin. 500 nüfusu) mahalle (köy) için de en yüksek yeterliliğe sahip müellif gerekli olmaktadır.

- 6360 sayılı yasa büyükşehir belediye (aynı zamanda il) sınırları içindeki en ücra köyleri bile büyükşehrin ve ilçe merkezinin mahallesi olarak kabul ettiği veri alındığında tümüyle kırsal nitelikli bu tür yerleşmeler içinde aynı prosedürün uygulanması kaçınılmaz olmaktadır. Uygulamada, büyükşehir belediyelerinin görev alanına giren kentteki güncel sorunların aciliyet sıralaması nedeniyle bu konuyu çoğunlukla öteledikleri gözlenmektedir. Hizmet talebi yoğunlaştığı yerlerde, böylesi köklü bir değişime hazırlıksız olan belediyeler, hizmet alanı içindeki kırsal yerleşmelere hizmet götürmekte zorlanmaktadır. Götürülen hizmetlerde de herhangi bir destek ve yönlendirme olmadığından ancak kendi sınırlı vizyon, kapasite ve deneyimleri ve el yordamı ile çalışmalar yapmaktadır.

\section{Sonuç ve Öneriler}

6360 sayılı yasa daha önce İstanbul ve Kocaeli için geçerli olan büyükşehir belediye sınırlarını il sınırlarına kadar genişletirken herhalde amacı kırsal alan tanımını ortadan kaldırmak değildi. İstanbul ve Kocaeli'nde il sınırlarının göreli olarak dar kapsamı, kentleşme düzeylerinin yüksekliği ve ulaşım olanaklarının gelişmiş olması nedeniyle kırsal alan ve kırsal yerleşim nitelikleri alışılmış görünümden uzaklaşmış olabilir. Ancak aynı uygulama diğer 28 ile de yaygınlaştıııldığında kırsal alan tanımı, yürürlükteki mevzuat ile belediye hizmetlerinin programlanması ve temininde güçlükler ortaya çıkmaktadır. Her şey bir yana, ülke toplam nüfusunun kentsel ve kırsal olarak oransal dağılımı bile yasa uygulamasının getirdikleri sonucu bugün anlamsızlaşmış, sağlıklı bir oran hesaplanması oldukça zahmetli bir duruma gelmiş bulunmaktadır.

Diğer taraftan, 2014 yılı Mart ayında gerçekleşen yerel seçimler öncesinde büyükşehir belediye statüsü verilmeyen illerin baskısı üzerine hazırlanan ve aynı uygulamanın nüfus büyüklüğüne bakılmaksızın tüm illere yaygınlaştırımasını hedefleyen (Bütünşehirler) kanun taslağı da ilk fırsatta gündeme gelmeyi beklemektedir. Bu konudaki taleplerin "büyükşehir belediyelerinin merkezden daha fazla pay almasının, diğer iller için büyükşehir statüsü elde etmeye çalışma bakımından teşvik edici olduğu .....listeye son anda giren Ordu iline Genel Bütçe'den ayrılan pay örneği ile desteklendiği" (Apan, 2016) belirtilmektedir. Bu yöndeki beklenti yakın geçmişte ziyaret edilen (Afyon, Adıyaman, Siirt, vb.) bir dizi il yönetimi tarafından dile getirilmiş bulunmaktadır. Gerçekleştiğinde geriye kalan 51 ilin tamamında il sınırları içi il merkezindeki belediyenin yetki ve sorumluluk alanı içinde olacak ve bugün salt büyükşehirler ile bağlantılı ortaya çıkan kırsal alan ve kırsal yerleşimler sorunu illerin tümüne yaygınlaşmış olacaktır.

Önümüzdeki yıllarda daha da artması beklenen büyükşehirlerin çevresindeki kırsal alan sorunun çözümü yönünde farklı bakış açılarından çeşitli öneriler getirilebilir. Bu çalışmada konu kırsal alanlara yönelik belediye hizmetleri ve bu kapsamda özellikle kent planlama odağında değerlendirilmekte ve öneriler geliştirilmektedir. 
Yukarıda adı geçen "Kırsal Alan Planlaması: Bir Model Önerisi" çalışmasının kırsal alanda yaşanan sorunlara bakışı "kent merkezli yaklaşım yalnızca kırsal alanların ekolojik, ekonomik ve toplumsal değişiminin düzensiz ve kendiliğinden bir sürece bırakmakla kalmamakta, aynı zamanda doğrudan kentsel alanlar için de sorunlar yaratmaktadır" tespitinden hareketle "Bu nedenle, mekânsal stratejilerin geliştirilmesinde, kırsal alanların özgün ekonomik, sosyal, kültürel yapısı ve ekolojik farklılıkları göz önünde tutularak ele alınması kaçınılmazdır. Ancak böyle bir ele alış günümüz kırsal yerleşmelerinde yaşanan dönüşümlerin [nüfus kaybı, nüfusun yaşlanması; ekonomik faaliyetlerdeki düşüş; kırın kent ve tüketim baskısı altına giderek daha fazla girmesi (dinlenme, eğlence, turizm vb. gelişmeler)] toplumsal açıdan dengeli bir biçimde yönlendirilmesini sağlayacaktır" önerisi getirilmektedir (Şenol vd., 2006).

Bütünüyle paylaşılan bu görüş uzantısında büyükşehirler ve etkilediği çevresindeki kırsal alan sorununa yönelik öneriler aşağıdadır;

- Kentsel ve kırsal yerleşme tanımlarının; Bakanlıklar, kamu kurumları, üniversiteler başta olmak üzere ilgili tüm çevrelerin katılım ve katkısı ile değerlendirilerek güncel verilerden hareketle yenilenmesi,

- Başlangıçta kentsel bir çevrede uygulanmak amaçlı hazırlanmış olan belediye kavramı ile öngörülen hizmetlerinin kırsal yerleşmeleri de kapsayacak şekilde yeniden tanımlanması ile kentsel ve kırsal yerleşmelere göre çeşitlendirilmesi,

- Bu çeşitlendirmenin; yerleşimlerin salt nüfus büyüklüğüne dayandırılması yerine onların coğrafi konumları, taban/tavan nüfus mertebeleri, yerleşim yoğunlukları ve sosyo - ekonomik özellikleri de dikkate alınması,

- Yerleşimlerin aşağıdaki beş ana kentleşme kademesinde gruplanması;

o Metropoller - Metropoliten bölgede yer alan en ileri kentleşme düzeyi ve nüfus büyüklüğüne (örn. en az 2 milyon) sahip metropoller ve uzantısı olan metropoliten bölge içinde yer alan bütünleşik diğer kentler,

○ Büyükşehirler - Kentsel alanda yer alan büyükşehir statüsündeki kentler, büyükşehirlerin merkezini oluşturan anakente dahil ilçe merkezleri ve nüfusları belli bir büyüklüğün (örn. en az 1 milyon) üstündeki diğer il ve ilçe merkezi olan kentler,

o Kentler - Kentsel olarak tanımlanabilecek alanda, anakente yakın ve/veya bitişik konumdaki ve kıyılarda (ve diğer özgün coğrafyalarda) yer alan en az orta (örn. en az 70.000) büyüklükte nüfusa sahip yerleşmeler,

○ Yarı - kırsal nitelikli yerleşimler olarak tanımlanabilecek olan büyükşehir belediye ve il sınırları içindeki nüfusu az (örn. 20.000 - 70.000 arası) ve gelişme potansiyeli düşük ilçe ve belde belediyeleri,

o Kırsal nitelikli yerleşimler, nüfusu 10.000 'den az olan beldeler köyler biçiminde nitelenmesi bu aşamada mevcut duruma açıklık kazandırabilecektir.

Bu kapsamda;

- Her kademedeki yerleşimde intiyaç duyulan çalışma ve hizmet esasları ile bunların teminine yönelik özgün mevzuat, yönetim, planlama ve yaklaşımının belirlenmesi,

- Belediye, imar ve planlama mevzuatının başta Çevre ve Şehircilik Bakanlığı olmak üzere, ilgili Bakanlıklar, kamu kurumları ve meslek odaları ile birlikte anılan yerleşme kademelenmesine göre gözden geçirilmesi, gerekli yasa ve yönetmelik değişikliklerinin yapılması,

- Yarı - kırsal ve kırsal nitelikli yerleşimlerde mevcut belediye ve yerel yönetimlerinin ilgili Bakanlık ile işbirliği içinde yenilikçi kırsal destek programlarını geliştirip uygulanması, 
- $\quad$ Uygulamayı yönlendirici öncü plan ve projeler ile belediye ve yerel yönetimlere destek verilmesi gerekmektedir.

\section{Kaynaklar}

Apan, A. (2016). "Büyükşehir Modeli ve Taşra Yönetimine Etkiler", Çağdaş Yerel Yönetimler, Cilt 25 Sayı 1.

Belik Kıray, M. (1972). Örgütleşemeyen Kent: İzmir'de İş Hayatının Yapısı ve Yerleşme Düzeni, Sosyal Bilimler Derneği Yayınları.

Şenol, P., Aydemir S. E. ve Aydemir, Ş. (2006). "Kırsal Alan Planlaması: Bir Model Önerisi”, TMMOB Şehir Plancıları Odası, Kent Planlama ve Koruma Etkinlikleri II - Koruma Sempozyumu, Trabzon.

GAP Bölge Kalkınma İdaresi. (2016). “Eğitim İhtiyaç Analizi ve Eğitim Eylem Planı”, Ankara.

Kentges. (2010). “Bütünleşik Kentsel Gelişme Strateji Belgesi ve Eylem Planı”, Ankara.

T.C. Tarım ve Köyişleri Bakanlığı. (2011). “Kırsal Kalkınma Planı 2010 - 2014”, Ankara.

T.C. Gıda Tarım ve Hayvancılık Bakanlığı. (2014). Ulusal Kırsal Kalkınma Stratejisi 2014 - 2020, Ankara.

T.C. Kalkınma Bakanlığı. (2014). “Bölgesel Gelişme Ulusal Stratejisi 2014 - 2023” Aralık 2014.

TUiK, 2015. Türkiye İstatistik Kurumu (TÜiK) Adrese Dayalı Nüfus Kayıt Sistemi (ADNKS), İl ve İlçe 2015 Nüfusları

URL-1. www.tüik.gov.tr, "Yıllara ve cinsiyete Göre il / ilçe merkezleri ve belde / köyler nüfusları 1927 - 2015", (Erişim Tarihi: 01 Kasım 2016) 